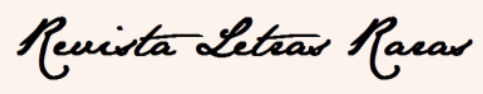

ISSN: 2317-2347 - v. 7, n. 2 (2018)

\title{
Poema a Heidegger
}

Ezequias da Silva Santos ${ }^{*}$

Porque há algo no lugar do nada?

O que é o nada senão o contrassenso

Do tudo? Que deveria existir

E não existe? Ou que existe mas não

É nada para nós que não sabemos

Que existe...?

Não conhecemos o nada, nem o tudo!

Nem a altitude nem a profundidade.

Porque o limite não está no senso,

Mas no contrassenso da razão.

E assim a dor existe, a morte existe.

Porque eu sou a vida que permite a morte.

Eu sou a vida que dá vida à morte.

Se em mim não houvesse vida,

Em mim não haveria morte.

E por mais que triunfe a morte

No fim dos dias da minha vida

Não será um triunfo memorável!

Afinal a morte só existe,

Pra que haja algo no lugar do nada.

Recebimento: 04/07/2018

Aceite: 18/09/2018

\footnotetext{
* Mestrando do PPGL em letras da UTFPR campus Pato Branco. E-mail: zekyjohnson@ hotmail.com
} 